\title{
A LOST OPPORTUNITY? OMISSION OF THE ILLUSORY TRUST DOCTRINE FROM THE TRUSTS ACT 2019
}

\author{
Thomas Probert*
}

\begin{abstract}
This article considers the role of the illusory trust doctrine in New Zealand. It argues that the illusory trust doctrine should be incorporated into the Trusts Act 2019. Incorporating the illusory trust will enhance clarity in New Zealand's law of trusts by providing the courts with a conceptually coherent method to assess the permissible boundaries of the trust. This article explores the differing views of illusory trusts in the context of the Trusts Act and in light of policy concerns. The "no meaningful accountability" view of illusory trusts is identified as the best formulation of the doctrine for incorporation into the Trusts Act. Importantly, the no meaningful accountability view does not jeopardise discretionary family trusts, which have social and economic significance. The author goes further by drafting a tentative provision for incorporation in the Trusts Act. The provision is then applied to the nefarious Clayton v Clayton trust and a typical, discretionary family trust. This application demonstrates that the provision will only catch the most nefarious Clayton-type trusts, thus preserving discretionary family trusts.
\end{abstract}

\section{INTRODUCTION}

The Trusts Act 2019 (the Act) is intended to implement a trusts law regime that articulates fundamental trusts concepts, thus providing clarity and accessibility in the law of trusts. ${ }^{1}$ Regrettably, the Act does not provide the clarity it seeks to achieve. ${ }^{2}$ The Act sets out the laws on express trusts, but crucially, does not specify the implications of non-compliance with such laws. Of course, it was contemplated that the courts continue to refer to the depth of the common law in this regard. ${ }^{3}$ When

\footnotetext{
* Solicitor, Mayne Wetherell. Submitted for the LLB (Honours) Degree, Faculty of Law, Victoria University of Wellington, 2019. The author would like to thank Dr Bevan Marten for his thoughtful supervision of this paper.

1 Trusts Bill 2017 (290-1) [the Bill]; and (6 December 2017) 726 NZPD 707.

2 Tobias Barkley "Submission to the Justice Committee on the Trusts Bill 2017" at 1.

3 (6 December 2017) 726 NZPD 707.
} 
a specific characteristic, right, power or obligation is breached or omitted from the trust deed, the ordinary consequences at law will follow. For example, a trustee exclusion of liability clause for dishonest breaches of trust is amendable. ${ }^{4}$ This creates few issues. However, what happens if there are two, three, four, or more problematic clauses in the trust deed? Such clauses may jeopardise the fiduciary relationship in which the trustee holds the property for the benefit of the beneficiaries, or may hinder trustee accountability. In those circumstances, can we genuinely say that a trust has been created? Under the law espoused in the Act, there is no clear answer. Without a conceptually coherent method for courts to undertake such analysis, a lack of clarity in the law of trusts will subsist.

The illusory trust doctrine should be incorporated into the Act to remedy the lacuna. An illusory trust is an arrangement that is not a trust due to the rights and obligations contained in the trust deed. ${ }^{5}$ The doctrine provides a tool by which the court can test trusts that come up for scrutiny. The court can consider the terms of the trust deed as a whole and come to a determination as to whether a trust is really a trust at all. However, there are a number of views of the illusory trust doctrine. ${ }^{6}$ This article assesses each view in light of the scheme of the Act and broader policy considerations. From a policy perspective, special care must be taken to ensure the discretionary family trust is not jeopardised by the illusory trust doctrine. The article identifies the "no meaningful accountability" view of the illusory trust doctrine as being best-suited for incorporation into the Act. The no meaningful accountability view forms the basis for a draft illusory trust provision proposed in this article for incorporation into the Act.

\section{THE CASE FOR AN ILLUSORY TRUST DOCTRINE A Contemporary Trusts Usage}

Trusts have a well-established legal core. ${ }^{7}$ This core can be broken down into two fundamental tenets of the trust. ${ }^{8}$ The first tenet is a fiduciary relationship, in which the trustee holds the trust property for the benefit of the beneficiaries. ${ }^{9}$ The second tenet can be described as "trustee accountability". ${ }^{10}$ Under this tenet, the trustee owes enforceable fiduciary obligations to the

4 Armitage v Nurse [1998] Ch 241 (CA).

5 Mark Bennett "Competing Views on Illusory Trusts: The Clayton v Clayton litigation in its wider context" (2017) $11 \mathrm{~J} \mathrm{Eq} 48$ at 49.

6 At $61-73$.

7 Andres Knobel Trusts: Weapons of Mass Injustice? (Tax Justice Network, 13 February 2017) at 9.

8 James Penner The Law of Trusts (10th ed, Oxford University Press, Oxford, 2016) at 21.

9 At 21.

10 Graham Virgo The Principles of Equity and Trusts (1 st ed, Oxford University Press, Oxford, 2012) at 48. 
beneficiary. ${ }^{11}$ These tenets will be explored in greater detail in Part III(A) of this article, but should be borne in mind from the outset. An illusory trust kicks sand in the face of the two fundamental tenets.

Bennett appositely notes the utility of the trust vehicle. He states: ${ }^{12}$

Trusts have always been a flexible legal arrangement that allowed a person to deliberately structure legal ownership and beneficial rights to property in ways that achieved purposes that could not be achieved at common law.

Facets of the trust have been revised to meet varying social and economic conditions throughout history. ${ }^{13}$ Such revision is an essential character of the law of trusts. ${ }^{14}$ Courts have recognised this and are slow to strike down contemporary trusts on the basis that their deeds enable greater settlor control over trust property or relax trustee accountability. This is not problematic insofar as the fundamental tenets of the trust are retained in the trust structure.

However, issues arise when practitioners, seeking to meet the exacting demands of private and commercial settlors, push the boundaries of the trust to the extent that the two fundamental tenets are jeopardised. ${ }^{15}$ The New Zealand trusts regime has become infamous because of its use by businesspeople to shelter assets from creditors. ${ }^{16}$ "All sources of [the settlor's] wealth; land, money, shares, or chattels can be protected by the use of a trust". ${ }^{17}$ Peart comments that property owners now have the ability to "reserve to themselves extensive powers of control over the trust". ${ }^{18}$ Practically, nothing changes for the settlor who vests their property on trust; they retain effective control over the property. However, they are safe in the knowledge that their assets are protected, should personal or financial difficulties arise. ${ }^{19}$ Peart hits the nail on the head when she reflects, "with careful planning,

11 Roderick Meagher, John Heydon and Michael Leeming Meagher, Gummow \& Lehane's Equity: Doctrines and Remedies (4th ed, LexisNexis, Chatswood (NSW), 2002) at 157.

12 Bennett, above n 5, at 54.

13 Law Commission Review of Trust Law in New Zealand: Introductory Issues Paper (NZLC IP19, 2010$)$ at 3.

14 Donovan Waters "The Trust in a Changed and Yet Changing World" (2008) 15 JTCP 205 at 242.

15 James Webb "An ever-reducing core? Challenging the legal validity of offshore trusts" (2015) 21 Trusts \& Trustees 476 at 486 .

16 Sue Tappenden "The role of equity in a changing society: from ancient Greece to present day New Zealand" (2015) 21 Trusts \& Trustees 389 at 396.

17 At 396.

18 Nicola Peart "Intervention to Prevent the Abuse of Trust Structures" [2010] NZLR 567 at 568.

19 At 568 
settlors have nothing to lose and everything to gain from placing their assets ... [on] trust" ${ }^{20}$ If this usage is paired with the tendency of the courts to dance around discussion of core trust principles and exacerbated by pervasive external regimes such as relationship property, there may be a movement from "an appreciation of the flexibility of the trust to a much more dangerous "flexibility" in our characterizations of what are the trust's essential features". ${ }^{21}$

Additionally, if courts continue to push core trust concepts to the periphery in their decisionmaking, we may be approaching something of an offshore trust jurisdiction. Offshore trusts are renowned for the "cherry picking of trust advantages" in a manner that is "unsound theoretically". ${ }^{22}$ Although it is probably a stretch to say we are already there, the practical implications of such a finding would be significant. ${ }^{23}$ Webb argues that offshore developments have turned the whole axis of the trust, to create extra advantages for the settlor. ${ }^{24}$ These advantages are said to "have concurrent disadvantages for wider society". ${ }^{25}$ Webb cautions that while offshore trusts "'serve an immediate end' for practitioners and their clients, they simultaneously violate the trust concept and harm others in society". 26

\section{$B$ Clayton v Clayton}

The Clayton v Clayton litigation is the raison d'être of problematic, contemporary trust usage. ${ }^{27}$ Mr Clayton held substantial business and personal assets on trust; the "Vaughn Road Property Trust" $(\mathrm{VRPT}){ }^{28} \mathrm{Mr}$ Clayton was the sole trustee, a discretionary beneficiary and the "Principal Family

20 At 568. Peart explains that changes in legislation in the past few decades have made trusts increasingly attractive as a mechanism for securing tax benefits, protecting assets from creditors and other unwanted claims, and avoiding means testing for state subsidies.

21 James Penner "Exemptions" in Peter Birks and Arianna Pretto (eds) Breach of Trust (Hart Publishing, Oxford, 2002) 241 at 267.

22 Webb, above n 15 , at 486.

23 At 486.

24 At 487

25 At 487

26 At 487.

27 MAC v MAC FC Rotorua FAM-2007-063-652, 2 December 2011 [Clayton (FC judgment)]; Clayton v Clayton [2013] NZHC 309, [2013] 3 NZLR 236 [Clayton (HC judgment)]; Clayton v Clayton [2015] NZCA 30, [2015] 3 NZLR 293 [Clayton (CA judgment)]; and Clayton v Clayton [2016] NZSC 29, [2016] 1 NZLR 551 [Clayton (SC judgment)].

28 Clayton (SC judgment), above n 27, at [11]. 
Member" of the VRPT. ${ }^{29}$ On an objective analysis, the VRPT deed can be said to omit both fundamental tenets of trust law. In his capacity as sole trustee, Mr Clayton was able to:

(a) pay or apply all of the income of VRPT to himself (as a discretionary beneficiary); ${ }^{30}$

(b) exercise all powers and discretions of the trustee, regardless of whether or not the interests of all beneficiaries had been considered, or whether the exercise of those powers or discretions would be contrary to the interests of any beneficiary; ${ }^{31}$

(c) exercise any power or discretion vested in the trustees in his own favour; 32

(d) exercise all powers and discretions of the trustee notwithstanding that the interests or duty of the trustee may conflict with the duty of the trustee to VRPT or any beneficiary; ${ }^{33}$ and

(e) vary, revoke or enlarge any terms of the VRPT deed (with the prior written consent of the Principal Family Member, which was also Mr Clayton). ${ }^{34}$

As trustee, Mr Clayton could not be liable for any breach of trust except in the case of a dishonest or wilful breach. ${ }^{35} \mathrm{Mr}$ Clayton had additional powers in his role as Principal Family Member of VRPT. Such powers included to add or remove any beneficiary, ${ }^{36}$ to add or remove any trustee, ${ }^{37}$ and to withhold consent to any variation of the VRPT deed. ${ }^{38}$

In proceedings between Mr and Mrs Clayton, the Family Court and High Court both held (albeit for different reasons) the VRPT was illusory. ${ }^{39}$ In the High Court, Rodney Hansen J formulated the illusory trust inquiry as whether, on the terms of the trust deed, Mr Clayton had retained such control that he did not give up or part with control over the property. ${ }^{40}$ Hansen J tacitly referred to the two core elements of the trust; a fiduciary relationship in which the trustee holds the property for the beneficiary and trustee accountability. His Honour was concerned that Mr Clayton was empowered

29 At [10].

30 VRPT Deed, cl 4.1(a) in Clayton (CA judgment), above n 27, at [25].

31 Clause 11.1(a)-(b).

32 Clause 14.1.

33 Clause 19.1(c).

34 Clause 23.1.

35 Clause 21.1. However, due to the extraordinarily wide powers afforded to Mr Clayton under the trust deed it was unlikely that a breach of trust would ever occur.

36 Clause 7.1.

37 Clause 17.1.

38 Clause 23

39 Jessica Palmer and Nicola Peart "Clayton v Clayton: a step too far?" (2015) 8 NZFLJ 114 at 114.

40 Clayton (SC judgment), above n 27, at [119]. 
to use and invest the property in any way he wished. ${ }^{41} \mathrm{Mr}$ Clayton could exercise any of his broad powers or discretions for his own benefit, without regard for the other beneficiaries' interests and notwithstanding any conflict of interest. ${ }^{42}$ This meant there was no effective delineation of property interests from the settlor, to the trustee (legal interest) and beneficiaries (beneficial interest). If there is no delineation of property interests between the trustee and beneficiary, there is no fiduciary relationship and the trust loses an essential character. ${ }^{43}$

The Court of Appeal overruled the Family Court and High Court on the illusory trust point. ${ }^{44}$ Bennett explains the illusory label is a proxy for the fundamental concepts of settlor control and trustee accountability. ${ }^{45}$ As the Family Court and High Court established, the VRPT clearly frustrated these concepts to the point of their non-existence. It is concerning the Court of Appeal was not prepared to make a finding that no trust had been created. Such a finding should have been made regardless of whether the "illusory" label was applied. The VRPT in Clayton has been described as an "offshore trust" in a recent, yet eminent treatise on trusts and modern wealth management. ${ }^{46}$ Despite this, the Court of Appeal preferred to classify Mr Clayton's powers under the trust deed as property, for the purposes of the Property (Relationships) Act 1976 (the PRA). ${ }^{47}$

The Supreme Court disagreed with the Court of Appeal's outright disregard for the illusory trust argument. ${ }^{48}$ However, it did not make a ruling on the doctrine. ${ }^{49}$ It considered the illusory analysis as a matter of some complexity that did not need to be decided. ${ }^{50}$ The Supreme Court also said that in cases where the trust deed gives the trustee the power to defeat the trust, courts would not need to make a finding on the status of the trust prior to the trustee's powers actually being exercised. ${ }^{51}$ This is problematic, as if the trust deed gives the trustee such powers, there is effectively no fiduciary relationship, nor trustee accountability. In those circumstances the irresistible conclusion is that no trust has been created. Instead, the Court was content to hold that Mr Clayton's VRPT powers were

41 Clayton (HC judgment), above n 27, at [90].

42 At [81].

43 Penner The Law of Trusts, above $\mathrm{n}$ 8, at 16.

44 Palmer and Peart, above n 39, at 114.

45 Bennett, above n 5, at 54.

46 Lusina Ho "Breaking Bad: Settlors' Reserved Powers" in Richard C Nolan, Kelvin FK Low and Tang Hang Wu (eds) Trusts and Modern Wealth Management (Cambridge University Press, Cambridge, 2018) 34 at 48.

47 Clayton (CA judgment), above n 27, at [116].

48 At [122]-[124].

49 At [133]

50 At [127].

51 At [125] 
relationship property. ${ }^{52}$ This demonstrates the Supreme Court's unwillingness to deal with the more fundamental question of "what is a trust?".

The Supreme Court delivered its judgment in Clayton, despite the parties having already settled the dispute. ${ }^{53}$ This was said to be appropriate given the importance of the legal issues raised. ${ }^{54}$ That is well-intentioned, but what legal issues have been resolved? We know that extreme levels of settlortrustee control will be treated as property, for the purposes of the PRA. However, as Bennett reflected post-Clayton, this does not solve any of the "big questions" about the nature of trust law. ${ }^{55}$

\section{The Trusts Act 2019 is Unsatisfactory in its Current Form}

The Law Commission's Review of the Law of Trusts (the Review) culminated in a finding that the current legislation underpinning trusts is unsatisfactory and in need of reform. ${ }^{56}$ The Review spanned from 2009 to $2013 .{ }^{57}$ It produced six issues papers, ${ }^{58}$ and one report. ${ }^{59}$ The Review ultimately resulted in the drafting of the Act.

In this vein, the Act is a robust attempt to reflect trust law as it currently exists in New Zealand. However, restricting the scope of the Act in this way is a lost opportunity to demarcate the boundaries of the trust. We are none the wiser as to when a putative trust has exceeded the permissible boundaries of the trust and will be struck down as such.

The illusory trust doctrine was not included in the Commission's terms of reference for the Review. ${ }^{60}$ There is no reference to the doctrine in the Commission's issues papers or report, nor in the

52 At [131].

53 At [3].

54 At [3].

55 Bennett, above $\mathrm{n} 5$, at 48 .

56 Law Commission Review of the Law of Trusts: A Trusts Act for New Zealand (NZLC R130, 2013) at IV.

57 Law Commission "Law of Trusts: Project Overview" <www.lawcom.govt.nz>.

58 The papers are: Law Commission Review of Trust Law in New Zealand: Introductory Issues Paper, above $\mathrm{n}$ 13; Law Commission Some Issues with the Law of Trusts in New Zealand: Review of the Law of Trusts Second Paper (NZLC IP20, 2010); Law Commission Perpetuities and the Revocation and Variation of Trusts (NZLC IP22, 2011); Law Commission The Duties, Office and Powers of a Trustee: Review of the Law of Trusts Fourth Issues Paper (NZLC IP26, 2011); Law Commission Court Jurisdiction, Trading Trusts and Other Issues: Review of the Law of Trusts Fifth Issues Paper (NZLC IP28, 2011); and Law Commission Review of the Law of Trusts Preferred Approach Paper (NZLC IP31, 2012).

59 Law Commission Review of the Law of Trusts: A Trusts Act for New Zealand, above n 56.

60 Law Commission "Law of Trusts: Project Overview", above n 57. 
Act itself. This article suggests three reasons as to why this omission may have occurred. These reasons are unsatisfactory.

First, there is an argument that through its articulation of fundamental characteristics of the trust and scheme of mandatory and default duties, the Act implicitly encapsulates the illusory trust doctrine. However, it is insufficient to simply espouse legal rules without specifying the implications that follow from non-compliance with such rules. This is especially important in the context of a trust deed with a conglomerate of provisions which, in aggregate, may jeopardise a fundamental tenet or tenets, of the trust.

Second, the Commission was undertaking their Review at the same time the Courts in the Clayton litigation were assessing the merits of the illusory trust doctrine. Therefore, it was arguably better to wait for a complete judicial exposition of the doctrine before coming to a view. This is specious. The paucity of trusts cases at appellate level has severely limited the ability of our courts to reason according to basic principles of trust law. The Clayton decisions have left trusts lawyers and scholars scratching their heads. ${ }^{61}$

Third, the illusory trust doctrine is arguably not sufficiently enshrined in trusts law to warrant any detailed assessment in the Review, nor incorporation in the Act. However, the illusory trust doctrine is simply the application of the idea that a trust is a particular kind of legal arrangement that has core features, and an arrangement that lacks them is not a trust despite using the vocabulary of trusts. ${ }^{62}$ The core features are the fiduciary relationship in which the trustee holds property for the benefit of the beneficiaries and trustee accountability, which are incorporated in s 13 of the Act. ${ }^{63}$ The illusory trust doctrine does not introduce any new constitutive elements of the trust. It reinforces existing ones.

\section{THEORY OF ILLUSORY TRUST}

\section{A Conceptual Underpinnings}

An illusory trust is an arrangement that is not a trust due to the rights and obligations contained in the trust deed; ${ }^{64}$ the putative settlor wanted to create a trust and intended to comply with the terms of the trust deed, but was mistaken in thinking that the deed created a trust. ${ }^{65}$

\footnotetext{
61 Palmer and Peart, above n 39, at 114.

62 Bennett, above $\mathrm{n} 5$, at 48 .

63 Set out in detail in Part IV(A) of this article.

64 Bennett, above $\mathrm{n} 5$, at 49 .

65 Palmer and Peart, above n 39, at 116.
} 
As noted above, there are two fundamental tenets of trust law. ${ }^{66}$ The illusory trust doctrine essentially evaluates a trust deed to see if these tenets are present. The first tenet is a fiduciary relationship, in which the trustee holds the trust property for the benefit of the beneficiaries ${ }^{67}$ In order to establish a trust, the settlor transfers his/her property to the trustee, who holds that property on trust for the benefit of the beneficiary. ${ }^{68}$ The trustee has legal ownership of the property and the beneficiary has beneficial ownership. ${ }^{69}$ Correlatively, the trustee is not entitled to use the property for his/her own benefit. ${ }^{70}$ Herein lies a fiduciary relationship between the trustee and beneficiary. ${ }^{71}$ At a fundamental level, fiduciaries are persons who make decisions in the interests of their principals. ${ }^{72}$ The trustee has legal powers to affect the legal position of his/her principal, the beneficiary. ${ }^{73}$ In exercising those powers, the trustee must only act in the interests of the beneficiary and must not allow his/her own interests, ${ }^{74}$ or the interests of third parties, to affect his/her judgment. ${ }^{75}$ If the terms of the trust deed reserve such control to the settlor or trustee that they are able to use the property for their own benefit, there is no fiduciary relationship. It cannot be said that the deed created a trust. A finding of an illusory trust may follow.

The second tenet can be described as "trustee accountability". ${ }^{76}$ The trustee owes fiduciary obligations to the beneficiary. ${ }^{77}$ Millet LJ referred to this tenet as the "irreducible core" in Armitage $v$ Nurse. ${ }^{78}$ He stated: ${ }^{79}$

66 Penner The Law of Trusts, above n 8, at 21.

67 At 21

68 Virgo The Principles of Equity and Trusts, above n 10, at 48. See also Ho, above n 46, at 46. In her discussion of the illusory trust, Ho explains it is an axiomatic principle in Anglo-common law that the trust involves the settlor's transfer of ownership to the trustee, subject to duties to deal with the property for the benefit of the beneficiaries.

69 Virgo The Principles of Equity and Trusts, above n 10, at 48

70 Penner The Law of Trusts, above n 8, at 21

71 At 23

72 At 23

73 At 23

74 Unless the trustee is also a beneficiary.

75 Penner The Law of Trusts, above n 8, at 23

76 Virgo The Principles of Equity and Trusts, above n 10, at 48

77 Meagher, Heydon and Leeming, above n 11, at 157.

78 Armitage v Nurse, above n 4, at 254

79 At 254 . 
There is an irreducible core of obligations owed by the trustees to the beneficiaries and enforceable by them which is fundamental to the concept of a trust. If the beneficiaries have no rights enforceable against the trustees, there are no trusts.

The fiduciary obligation to benefit others is a fundamental, constituent element of the trust. ${ }^{80}$ The corollary is that the duty of the trustees to perform the trusts honestly and in good faith for the benefit of the beneficiaries is the minimum standard necessary to give effect to a trust. ${ }^{81}$ If the trust deed renders the beneficiary unable to hold the trustee accountable, a finding of an illusory trust may follow.

These two tenets sit alongside the three certainties needed to constitute a trust; certainty of intention, certainty of object and certainty of subject. ${ }^{82}$ Cases of illusory trusts tend not to hinge on the three certainties; the settlor always intended to create a trust. The settlor invariably specifies the subjects and identifies the putative objects of the trust.

\section{B Illusory Trusts are not Shams}

The illusory trust is distinct from the sham trust. The doctrines can be distinguished on two bases. First, a sham occurs when the settlor and trustee share "a common, dishonest intention to create the appearance of a trust, but agree to be bound in reality by a contrary legal relationship". ${ }^{83}$ As Birss J noted in the English and Welsh High Court case JSC Mezhdunarodniy Promyshlenniy Bank $v$ Pugachev, the illusory analysis is "not concerned with the subjective intentions of the parties to create a pretence to mislead". 84

Second, reservation of powers to the settlor, no matter how extensive, will not render the trust a sham. ${ }^{85}$ A sham will arise if the pattern of conduct subsequent to the establishment of the trust "contradicts with ... [the settlor's] pretence in the trust deed to part with the property and set up a

80 Tobias Barkley "The Content of the Trust: What Must a Trustee be Obliged to Do With the Property?" (2013) 19 Trusts \& Trustees 452 at 453.

81 Armitage v Nurse, above $\mathrm{n} 4$, at 254. The concept is largely attributable to David Hayton, who identified the concept of an irreducible core: David Hayton "The Irreducible Core Content of Trusteeship" in AJ Oakley (ed) Trends in Contemporary Trust Law (Clarendon Press, Oxford, 1996) 47.

82 The "three certainties" requirement originates from Knight v Knight (1840) 49 ER 58 (Ch). See also Penner "Exemptions", above n 21, at 190.

83 Ho, above n 46, at 39-40. The requirement of common intention applies except if the settlor and the trustee is the same person.

84 JSC Mezhdunarodniy Promyshlenniy Bank v Pugachev [2017] EWHC 2426 (Ch), 20 ITELR 905 at [168].

85 Ho, above n 46, at 40. 
trust". ${ }^{86}$ In contrast, the conduct of the parties to the trust is not relevant to a finding of an illusory trust. The illusory trust doctrine focuses solely on the trust deed. ${ }^{87}$

This article does not consider the sham doctrine. The Commission analysed the law on sham trusts in their Review. ${ }^{88}$ It concluded that future trusts legislation should not contain any provisions relating to finding that a trust is a sham trust. ${ }^{89}$

Illusory trusts are also conceptually distinct from "alter ego trusts". The alter-ego concept involves viewing the trust as the alter ego of an external controller such as the settlor. ${ }^{90}$ It is similar to a finding of a sham, in that the level of control relinquished by the trustee, to the controller, indicates that the trust structure is a façade that can be disregarded. ${ }^{91}$ Alter ego trusts are not considered in this article.

\section{Illusory Trusts in Jurisprudence and Literature}

O'Hagan suggests the principal desire amongst settlors is to "retain the ability to reverse what has been put in place and get the trust assets back if circumstances warrant it"..$^{92}$ This desire manifests in a settlor retaining dispositive powers such as powers of appointment, or administrative or investment powers. If the settlor can call for the capital of the trust without formality, then purported beneficial interests are illusory. ${ }^{93}$ Therefore, one can determine from the terms of the trust deed whether the trust is illusory.

The illusory trust doctrine has been considered in other commonwealth jurisdictions. It was argued extensively in Pugachev. ${ }^{94}$ In that case, Mr Pugachev was the settlor and protector of five New Zealand trusts with near-identical trust deeds. ${ }^{95}$ The deeds enabled Mr Pugachev to appoint beneficiaries, appoint and remove trustees, and direct the trustees to sell trust property. ${ }^{96}$ Significantly,

86 At 40

87 Pugachev, above n 84, at [168]. See also ND v SD [2017] EWHC 1507 (Fam), [2018] 1 FLR 1489 at 176.

88 Law Commission Some Issues with the Law of Trusts in New Zealand: Review of the Law of Trusts Second Paper, above n 58, at 39-43.

89 Law Commission Review of the Law of Trusts Preferred Approach Paper, above n 58, at 38.

90 Law Commission Some Issues with the Law of Trusts in New Zealand: Review of the Law of Trusts Second Paper, above n 58, at 44.

91 Official Assignee v Wilson [2007] NZCA 122, [2003] 3 NZLR 45 at [64].

92 Patrick O'Hagan "The reluctant settlor - property, powers and pretences" (2011) 17 Trusts \& Trustees 905 at 905.

93 At 906

94 Pugachev, above n 84, at [155]-[172].

95 At [142].

96 At [115]. 
Mr Pugachev's consent was required in order for a trustee to exercise any power or discretion to distribute or invest trust income and capital, remove beneficiaries, vary the trust deed, revoke any power of the trustee or change the date of distribution. ${ }^{97}$ Birss $\mathrm{J}$ found, in substance, that the trusts in question were illusory. ${ }^{98}$ However, his Honour found the term "illusory" to be unhelpful; rather, he considered the issue from a "true effect of the trusts" perspective. ${ }^{99}$

In $B Q v D Q$ the Supreme Court of Bermuda set aside two trusts on the basis that their form rendered them illusory. ${ }^{100}$ Ground $\mathrm{CJ}$ held that the concatenation of rights and powers in the settlor, when coupled with the fact that he was the sole trustee at the time of the constitution of the trusts, rendered the trusts illusory during his lifetime. ${ }^{101}$

However, Palmer opines that Ground CJ's finding could only be correct if one of the powers "retained by the settlor has the effect of vitiating any of the obligations owed by the trustee to the beneficiaries so that there is no accountability". ${ }^{102}$ Article VIII(H) of the trust deed has this effect: ${ }^{103}$

The written approval by the Donor [the settlor] of any trust transaction during his lifetime shall be a complete release of the Trustee (including the Donor) of any liability or responsibility of the Trustee to any person with respect to this transaction.

Article VIII (H) "enable[s] the settlor to render the beneficiary's right to hold the trustee to account meaningless". ${ }^{104}$ For Palmer, it is the fact of no accountability, as opposed to the lack of delineation of property interests identified by Ground CJ, that provides justification for a finding of an illusory trust.

97 At [115].

98 Grahame Young "Sham and illusory trusts - lessons from Clayton v Clayton" (2018) 24 Trusts \& Trustees 194 at 200

99 At 200

$100 B Q v D Q$ [2010] SC (Bda) 40 Civ, 13 ITELR 260 at [29].

101 At [29].

102 Jessica Palmer "Controlling the Trust" (2011) 12 Otago L Rev 473 at 485 (emphasis added).

$103 B Q v D Q$, above n 100, at [7], as cited in Palmer, above n 102, at 485 .

104 Palmer, above n 102, at 485. 


\section{FORMULATING THE ILLUSORY TRUST DOCTRINE FOR THE TRUSTS ACT}

The jurisprudence and literature shows there are differences in the formulation of the illusory trust doctrine. These differences are well-articulated by Bennett, who sets out a taxonomy of "narrow views" and "wide views", of the illusory trust. ${ }^{105}$

Narrow views of the illusory trust focus on the formal existence of trust obligations. ${ }^{106}$ There are two species of narrow view. These are the "no accountability" and "trustee usurpation" views. ${ }^{107}$ Wide views, on the other hand, doubt the flexibility of the trust concept to accommodate the more extreme settlor-controlled or trustee benefitting arrangements. ${ }^{108}$ There are three species of wide view. These are the "unlimited benefit", "no meaningful accountability", and "reality of control" views. ${ }^{109}$ At a general level, all views follow the concept that a trust is only legitimate when the two fundamental tenets outlined above are adhered to. The difference lies in the extent to which the views consider that adherence to be meaningful.

It is necessary to subscribe to one of the above views of the illusory trust doctrine for incorporation into the Act. However, this view must reflect the scheme of the Act. Additionally, as a matter of policy, special care must be taken to ensure the discretionary family trust is not jeopardised by the illusory trust doctrine. ${ }^{110}$ This article will briefly survey the provisions of the Act relevant to the illusory trust doctrine. The different views of the illusory trust doctrine are then set out in more detail and evaluated with the scheme of the Act and policy considerations in mind. The evaluation will inform a preferred view of an illusory trust, for incorporation into the Act.

\section{A Relevant Provisions of the Trusts Act}

Section 13 sets out two characteristics of the express trust. First, s 13(a) explains that a trust is "a fiduciary relationship in which a trustee holds or deals with trust property for the benefit of the beneficiaries". Section 13(a) reflects the delineation of property interests tenet of the trust at common law. ${ }^{111}$ Second, s 13(b) states the trustee must be "accountable for the way the trustee carries out the duties imposed on the trustee by law". This reflects the "trustee accountability" tenet of the trust.

105 Bennett, above n 5, at 61-73.

106 At 60.

107 At $61-65$.

108 At 64

109 At $65-73$

110 See the discussion of this issue in Part IV(C)(1)-(2).

111 It is complemented by s 14 , which provides that a sole trustee must not also be the sole beneficiary of the trust. 
Section 13(b) interacts with the Act's mandatory and default trustee duties, its rules on trustee exemption and indemnity for breach of trust and its requirement to provide trust information. Section 22 explains that the trustee duties set out in ss 23-27 are mandatory duties that "must be performed by the trustee" and may not be excluded or modified by the terms of the trust. ${ }^{112}$ Section 28 provides that the duties in s 29 to 38 "are default duties that must be performed by the trustee unless modified or excluded in accordance with section 5(4) and (5)". 113

Sections 40 and 41 of the Act help to ensure trustee accountability. Section 40 prohibits the limitation or exclusion of the trustee's liability "for any breach of trust arising from the trustee's dishonesty, wilful misconduct, or gross negligence". Section 41 prohibits the use of indemnity clauses "against the trust property for liability for any breach of trust arising from the trustee's dishonesty, wilful misconduct, or gross negligence".

Section 51(1) deals with the provision of trust information to the beneficiaries. It provides "[t]here is a presumption that a trustee must make available to every beneficiary or representative of a beneficiary ... basic trust information". ${ }^{114}$ However, before giving the information, "the trustee must consider the factors set out in section 53", and may conclude the presumption does not apply in light of those factors. ${ }^{115}$ Section 51 reflects the Commission's desire to further accountability in the law of trusts. ${ }^{116}$ Therefore, any formulation of the illusory trust doctrine should consider availability of trust information to the beneficiaries, under the banner of trustee accountability.

Sections 13(a) and 13(b) of the Act (along with their supplementary provisions) reflect the fundamental tenets of the trust. The requirements of a fiduciary relationship and trustee accountability is essentially the Act. It makes sense that the illusory trust doctrine is applied to test these requirements. A consistent, practical application of the Act is what will create certainty in the law of trusts. The Act continues to allow the courts to refer to the common law when interpreting and

112 The mandatory duties are: to know the terms of the trust (s 23); to act in accordance with terms of the trust (s 24); to act honestly and in good faith ( $\mathrm{s} 25$ ); to deal with trust property, or otherwise act, for the benefit of the beneficiaries (or further a permitted purpose) (s 26); and to exercise powers for a proper purpose (s 27).

113 The default duties are: general duty of care (s 29); to invest prudently (s 30); to not exercise power for own benefit (s 31); to consider exercise of power (s 32); not to bind or commit trustees to future exercise of discretion (s 32); to avoid conflict of interest (s 33); to act impartially ( 34 ); not to profit from the trust ( $\mathrm{s}$ 35 ); to act for no reward (s 36); and to act unanimously (when there is more than one trustee) (s 37).

114 The basic trust information is: the fact that a person is a beneficiary of the trust (s 51(3)(a)); the name and contact details of the trustee (s 51(3)(b)); the occurrence of, and details of, each appointment, removal, and retirement of a trustee as it occurs (s 51(3)(c)); and the right of the beneficiary to request a copy of the terms of the trust or trust information (s 51(3)(d)).

115 Trusts Act 2019, s 51(2)(a)(ii).

116 Law Commission Review of the Law of Trusts Preferred Approach Paper, above n 58, at 68. 
applying its provisions. ${ }^{117}$ Section 5(8)(a) states that the Act is not an "exhaustive code" of the laws of express trusts, and the Act is intended to be supplemented by the rules of common law and equity relating to trusts. In keeping with the scheme of the Act, the formation of the illusory trust doctrine will provide a framework for the courts to decide cases, while case law continues to perform an auxiliary function.

\section{B Narrow Views}

\section{No accountability}

Under the no accountability view, the trust is illusory when none of the trustees' purported obligations are enforceable by the beneficiaries. This view is grounded in the concept of the irreducible core and reflected in s 13(b) of the Act. As outlined above, s 13(b) identifies a characteristic of the express trust as the trustee being accountable "for the way the trustee carries out the duties imposed on the trustee by law". If the trust deed contains no enforceable obligations on the trustee at all, there is plainly no accountability and there is no trust. While the no accountability view provides a starting point for an illusory trust, we need to go further. The doctrine should apply not only to trusts where lack of accountability is manifest in a single provision in the trust deed, but also where a combination of provisions operates to prevent trustee accountability in practice.

\section{Trustee usurpation}

Under the trustee usurpation view, the trust is illusory when the trustee's discretions can be "completely overborne by the decisions of another". ${ }^{118}$ The "other" is invariably the settlor of the trust, so the trustee usurpation view could equally be termed the "settlor control" view. This view reflects that there must be a delineation of property interests from the settlor, to the trustee and beneficiary. If the trustee's discretion can be completely overborne, there is no true division of legal and beneficial interest in the trust property. This compromises the fiduciary relationship between the trustee and beneficiary. In such a case, the trust would be contrary to the Act. Section 13(a) states that a trust is a fiduciary relationship in which the trustee holds or deals with trust property for the benefit of the beneficiaries. Therefore, the trustee usurpation view is a useful conceptual starting point. However, it cannot form the basis of the illusory trust doctrine in its entirety. It is principally concerned with the powers of the settlor in relation to the trust, as opposed to a more holistic consideration of the practical effect of the obligations imposed on the trustee.

117 (6 December 2017) 726 NZPD 707.

118 Bennett, above n 5, at 60. See also Hayton, above n 81, at 65 . 


\section{Wide Views}

\section{Unlimited benefit}

According to the unlimited benefit view, the trust is illusory if the trustee can take the benefit of the trust property, to the detriment of the beneficiary. ${ }^{119}$ A clause in a trust deed permitting the trustee to self-benefit may jeopardise the delineation of legal and beneficial ownership between trustee and beneficiary. Correlatively, it will also conflict with the trustee's fiduciary obligation to hold trust property for the beneficiaries. ${ }^{120}$ Bennett cogently notes: ${ }^{121}$

The idea that the trustee should not be able to distribute all the trust property to themselves is implicit in the axiomatic trusts law idea of the trustee being a fiduciary steward of property they hold for the benefit of others.

The key fiduciary obligation to hold trust property for the beneficiaries is excluded, because the trustee is expressly given the power to benefit herself over another. ${ }^{122}$ If the provisions have this effect, the trust is illusory. This appears to have been Hansen J's approach in the High Court in Clayton. ${ }^{123}$ Thus, the unlimited benefit view looks at the impugned provisions of the trust deed as a whole to see whether the trustee is empowered to use and invest the property in any way they wish. ${ }^{124}$ If they can, there is no delineation of property interests, nor a fiduciary relationship.

Trustee accountability is also implicitly captured by the unlimited benefit view. A hallmark of trustee accountability is whether a trustee, in practice, holds their power in a fiduciary capacity to the object of the trust. ${ }^{125}$ As this article has explained, unlimited trustee self-benefit means there is no delineation of property interests and the fiduciary character of the relationship is denied. In such trusts, the trustee does not have to exercise his/her power for the benefit of the beneficiary. By the very nature of the arrangement, it will be difficult to call the trustee to account for an exercise of the trust.

However, the Act implicitly permits "massively discretionary trusts", which may be jeopardised under the unlimited benefit view. ${ }^{126}$ Discretionary trusts are trust structures in which the trustee holds

119 Bennett, above n 5, at 64

120 At 66.

121 At 66 .

122 At 20 .

123 At 66.

124 Clayton (HC judgment), above n 27, at [90].

125 Penner The Law of Trusts, above n 8, at 74.

126 Barkley "Submission to the Justice Committee on the Trusts Bill 2017", above n 2, at 1. 
some or many dispositive discretions. ${ }^{127}$ In some cases, the trustees' dispositive discretions effectively govern the whole trust, such that the beneficial interests under the trust are not only qualified, but potentially displaced. ${ }^{128}$ The distinction between discretionary and final beneficiaries becomes false, because the final beneficiaries "will only benefit if the trustee chooses to let them benefit". ${ }^{129}$ The Commission declined to engage with discretionary trusts as a substantive matter for reform, and this is reflected in the lack of distinction between fixed and discretionary trusts in the Act. ${ }^{130}$ Problematically, if a trustee-beneficiary has discretionary powers to appoint any or all of the trustee property to any beneficiary, they may have powers of unlimited self-benefit. There is a risk the trust would be illusory on the unlimited benefit view. This is contrary to the legislative and policy intention to allow such trusts to subsist. In order to justify the unlimited benefit view of the illusory trust doctrine, this article would have to demonstrate why it is sound in law and policy to capture massively discretionary trusts as illusory. That is a separate issue and not within the purview of this article. ${ }^{131}$

It follows that the illusory trust doctrine must strike a balance between catching nefarious uses of the trust, as in Clayton, on one hand, and preserving discretionary family trusts on the other. The 2013 Census suggested that 215,280 dwellings, or 14.8 per cent of all occupied private dwellings, were held in a family trust by the usual residents of the dwelling. ${ }^{132}$ This is significant. It suggests a widecross section of the community is using a discretionary family trust to protect the family home. Such usage is of great utility; it provides asset protection benefits, enables succession planning and enhances flexibility in the family home. ${ }^{133}$ Discretionary family trusts are thus socially and

127 See generally Lionel Smith "Massively Discretionary Trusts" in Richard C Nolan, Kelvin FK Low and Tang Hang Wu (eds) Trusts and Modern Wealth Management (Cambridge University Press, Cambridge, 2018) 130 .

128 At $131-132$.

129 Barkley "Submission to the Justice Committee on the Trusts Bill 2017", above n 2, at 1-4.

130 Lucie Greenwood "Discretionary Trusts - what happened to 'practical intelligence' in the law?" (LLB (Hons) Dissertation, University of Otago, 2012) at 1.

131 Barkley "Submission to the Justice Committee on the Trusts Bill 2017", above n 2, presents a strong argument as to why massively discretionary trusts should be treated differently from fixed trusts. This article does not express a view on the normative desirability of making a distinction between fixed and discretionary trusts in the legislation. However, this issue surely warrants further consideration from the Law Commission.

132 Statistics New Zealand "2013 Census QuickStats About Housing" <www.stats.govt.nz>. See generally Phil Briggs Family trusts: ownership, size, and their impact on measures of wealth and home ownership (Reserve Bank of New Zealand, DP 2006/06, July 2006).

133 Law Commission Review of Trust Law in New Zealand: Introductory Issues Paper, above n 13, at 6. 
economically important. To disturb them would be contrary to the interests of "mum and dad" home owners and investors. ${ }^{134}$ Only the most nefarious, Clayton-type trusts should be rendered illusory. ${ }^{135}$

Discretionary family trusts by their very nature give the trustee broad discretionary powers. The trustee is typically also a discretionary beneficiary and will be able to appoint some or all of the trust income or capital to themselves, as beneficiary. ${ }^{136}$ This risks a finding of an illusory trust on the unlimited benefit view. Therefore, the appropriate balance cannot be struck using the unlimited benefit view.

\section{No meaningful accountability}

Under the no meaningful accountability view, the trust deed should not provide for simply any accountability of the trustee to the beneficiaries, but meaningful accountability. ${ }^{137}$ It is a wide view because it looks at whether there is trustee accountability in substance. ${ }^{138}$ Despite using the terminology of "accountability", this view encompasses the two fundamental tenets of the trust described in this article, and reflected in s 13(a) and (b) of the Act.

First, as with the unlimited benefit view, an indicia of meaningful accountability is whether a trustee, in practice, holds their power in a fiduciary capacity to the object of the trust. ${ }^{139}$ Therefore, the no meaningful accountability view reflects s 13(a) of the Act, that a trust is a fiduciary relationship in which the trustee holds or deals with trust property for the benefit of the beneficiaries. This article has explained that unlimited self-benefit will usually omit a fiduciary relationship. However, the no meaningful accountability view requires more than the ability of the trustee to take an unlimited benefit from the trust. ${ }^{140}$ As Palmer and Peart have explained in relation to Clayton: ${ }^{141}$

Because the powers Mr Clayton conferred upon himself were so wide-ranging, he was the sole trustee and

important fiduciary duties were excluded, arguably there was little evidence of any meaningful

134 At 4

135 But see Sue Tappenden "The Family Trust in New Zealand and the Claims of 'Unwelcome Beneficiaries'" (2009) 2(4) Journal of Politics and Law 17. Tappenden suggests "[w]hile there is nothing illegal in setting up a family trust ... the law pertaining to family trusts in New Zealand has become so far removed from the accepted principles of equity as to demand investigation" (at 17).

136 New Zealand Law Society The Family Trust (11 March 2013).

137 Bennett, above n 5, at 64

138 At 73 .

139 Penner The Law of Trusts, above n 8, at 74.

140 Bennett, above n 5, at 72 .

141 Palmer and Peart, above n 39, at 124. 
accountability. Such accountability is central to the existence of a trust and might suggest a lack of trust intention.

Bennett elaborates on the point. He explains that even if a sole trustee can appoint trust property to themselves, that power is a fiduciary power and is subject to fiduciary duties in its exercise. ${ }^{142}$

Palmer and Peart's view is reflected in the well-established rule that the trustee is permitted to take some benefit from the trust. ${ }^{143}$ The no meaningful accountability view does not capture all situations of trustee self-benefit. The trust deed may authorise the trustee to benefit from the exercise of a trust power, but the nature of the power is limited so that the trustee cannot completely disregard all others' interests. ${ }^{144}$ This includes the discretionary family trust. Discretionary family trusts are thus consistent with the core of the trust, as fiduciary obligations still exist. ${ }^{145}$ Traditional mechanisms used to restrict the exercise of fiduciary powers will still apply,. ${ }^{146}$ Such mechanisms include excessive execution of a trustee power, fraud on a power, conflict of interest, relevant and irrelevant considerations, and irrationality. ${ }^{147}$

Contrastingly, the trust deed in Clayton excluded not only fiduciary constraints, but conferred significant other powers on Mr Clayton such that the intention to create a trust would be in doubt. ${ }^{148}$ These powers included the ability to appoint all the income and capital to Mr Clayton without having the duty to act impartially or consider all beneficiaries' interests, to act in a conflict of interest situation and to remove all other beneficiaries from the trust. ${ }^{149}$ No meaningful accountability requires extreme levels of trustee control as evident in Clayton, such as the ability to act without considering the interests of the beneficiaries, or to act in a conflict of interest situation. ${ }^{150}$ Extreme levels of control tend not to occur in discretionary family trusts and so those trusts will not be caught. The no meaningful accountability view is therefore more suitable to upholding the distinction between Clayton-type trusts and socially acceptable discretionary family trusts.

In permitting some trustee self-benefit, the no meaningful accountability view reflects the scheme of the Act. Section 26 imposes a mandatory duty on the trustee to "hold or deal with trust property

142 Bennett, above n 5, at 64.

143 Barkley "The Content of the Trust", above n 80, at 3.

144 At 3 .

145 Penner The Law of Trusts, above $\mathrm{n} 8$, at 70 .

146 RC Nolan "Controlling Fiduciary Power" (2009) 68 CLJ 293 at 293.

147 At 293

148 Bennett, above n 5, at 64.

149 Palmer and Peart, above n 39, at 118

150 Bennett, above n 5, at 72-73. 
and otherwise act for the benefit of the beneficiaries". This is a clear exposition of the fiduciary nature of the trust relationship between the trustee and beneficiary. However, s 31 creates a default rule that the trustee cannot benefit from the trust. As this rule can be overridden by the trust deed, it must be possible for the trustee to take some benefit from the trust property.

Second, the no meaningful accountability view plainly contemplates trustee accountability as it is formulated in s 13(b) of the Act. Part of the accountability analysis is whether, as explained above, the trustee holds their powers in a fiduciary capacity. However, accountability also encompasses trustee exclusion of liability and indemnity provisions for breach of trust. Incorporation of such provisions in the trust deed may significantly hinder the accountability of the trustee to the beneficiary. These concepts are embedded in the Act. Sections 40 and 41 prohibit the exclusion of liability or indemnification for a breach of trust that is grossly negligent, dishonest, or a wilful breach. Additionally, knowledge of the basic terms of the trust by the beneficiary is crucial to holding the trustee to account. ${ }^{151}$ Section 51 creates a rebuttable presumption in favour of disclosing basic trust information to the beneficiaries. Therefore, the scope and extent of any bar on the provision of trust information to the beneficiaries will form part of the illusory trust inquiry, under the no meaningful accountability view.

\section{Reality of control}

Reality of control looks beyond the strict legal form of the arrangement. As Bennet explains: ${ }^{152}$ It examines whether in substance or 'reality' the powers provided in the trust deed to the settlor or trustee mean that they, rather than the specified beneficiaries, have the benefit of the property.

Issues of extensive trustee (or settlor-trustee) control are captured by the no meaningful accountability view, making the reality of control view redundant in this respect. However, the no meaningful accountability view looks solely at the position of the trustee. The reality of control view is essential for demarcating the role of the settlor, when the settlor is not a trustee or beneficiary.

A reality of control is likely to exist where the settlor is not a trustee, but retains powers to control how the trust property is used. For example, the settlor may reserve powers under the trust deed to give binding directions for investment, to give or withhold consent for the exercise of the trustee's powers, to replace trustees, to direct the distribution of trust assets contrary to the terms of the trust deed or to act as a director of a company whose shares are owned by the trust. ${ }^{153}$ If these powers exist in the trust deed, they obfuscate the delineation of property interests between trustee and beneficiary

151 Law Commission Review of the Law of Trusts Preferred Approach Paper, above n 58, at 65-71.

152 Bennett, above n 5, at 69

153 At 69. 
upon transfer. If the settlor is exercising control over the trustee, they essentially have a legal interest in the property. If the settlor is exercising that control to take a benefit from the property, they have a beneficial interest.

Excessive settlor control is contrary to s 13(a) of the Act. Section 13(a) explains that the trust is a fiduciary relationship in which the trustee holds or deals with the trust property for the benefit of the beneficiaries. It could be said that if control of the trust lies with the settlor, the trustee is not holding the property for the benefit of the beneficiaries, thus abandoning the requisite delineation of property interests. It may follow that the trustee does not hold their power in a fiduciary capacity to the object of the trust. This is repugnant to the concept of the trust, both at common law and under the Act. Therefore, it would be favourable to incorporate reality of control of the settlor into an analysis of whether the trust is illusory.

\section{Preferred View}

The value of the illusory trust doctrine, in relation to the Act, lies in the adaption of the wide views. Courts must be able to look to the substance of the trust deed to see whether the fundamental tenets of the trust are jeopardised.

The no meaningful accountability view should form the basis of the illusory trust doctrine for the Act. The trust will be illusory if there is no meaningful accountability on the part of the trustee to the beneficiaries. If there is no meaningful accountability, the trustee does not hold their powers under the trust in a fiduciary capacity. It follows that the trustee is not accountable for the way the trustee carries out the duties imposed on the trustee by law. In this way, the no meaningful accountability view accounts for the two fundamental tenets of the trust.

As the no meaningful accountability view imposes a higher threshold than unlimited benefit, discretionary family trusts will be protected from a finding of an illusory trust. The interaction of the doctrine with a typical family trust, compared to the nefarious Clayton trust, is set out at Part VII below. The ability to strike a balance between Clayton-type trusts and discretionary family trusts is the determinative reason why the no meaningful accountability view should be preferred.

The trade-off is that some massively discretionary trusts will remain permissible. However, the alternative is untenable in light of the social and economic importance of discretionary family trusts in New Zealand. It is worth bearing in mind there is always a risk of people using trust structures inappropriately. However, so long as the two fundamental tenets of the trusts are present, inappropriate use will run contrary to the terms of the trust deed, giving rise to a cause of action on the part of the beneficiaries. It has been shown that the discretionary family trust incorporates these two tenets. Additionally, external regimes will still be able to look through discretionary trusts in the usual circumstances. In light of this, the no meaningful accountability view is most consonant with the Act and policy concerns. 
The no meaningful accountability view needs to be built upon in one respect, for incorporation into the Act. A reality of control inquiry must be added. However, this will be restricted to settlor control, where the settlor is not a trustee. A reality of control may exist where the settlor retains control of how the trust property is used. This obscures the fiduciary relationship between the trustee and beneficiary, jeopardising a fundamental tenet the trust.

\section{DRAFT PROVISION}

The following draft provision "s $140 \mathrm{~A}$ " is proposed. Section $140 \mathrm{~A}$ enables the court to make a finding of an illusory trust, in accordance with the no meaningful accountability view. It will be situated at the bottom of pt 7 of the Act, which mandates court powers and dispute resolution.

140A Court may declare trust illusory

(1) The court may declare the trust illusory, if it is satisfied that in substance, the terms of the trust deed provide no meaningful accountability on the part of the trustee, to the beneficiaries.

(2) In determining whether the terms of the trust deed provide no meaningful accountability, the court must have regard to-

(a) whether the trust deed in substance omits a fiduciary relationship in which the trustee holds or deals with trust property for the benefit of the beneficiaries, within the meaning of section 13(a); and

(b) whether the trust deed in substance prevents the trustee from being accountable for the way the trustee carries out the duties imposed on the trustee by law, within the meaning of section 13(b).

(3) Subsection (2) does not limit the matters the court may have regard to.

(4) If the settlor is not a trustee, the court may make a declaration that the trust is illusory if it is satisfied that the terms of the trust deed give the settlor real control of the trust property.

(5) Where the court makes a declaration that the trust is illusory, the trust is a resulting trust for the settlor.

(6) The court may decline to make a declaration of an illusory trust if it considers that to do so would unfairly prejudice the interests of the other parties to the trust, or the interests of third parties.

\section{ANALYSIS OF S 140A}

\section{A What Kind of Reform is $s$ 140A?}

Section 140A does not substantively alter the requisite core of the trust. In framing the no meaningful accountability inquiry around two mandatory considerations, per s 140A(2), the doctrine 
is squarely focused on the two fundamental tenets of the trust outlined in this article. These tenets are affirmed in $\mathrm{s} 13$ of the Act.

The $\mathrm{s} 140 \mathrm{~A}(2)(\mathrm{a})$ and $140 \mathrm{~A}(2)(\mathrm{b})$ inquiries will draw on existing factors identified in the jurisprudence and literature. For example, the omission of a fiduciary relationship per s $140 \mathrm{~A}(2)(\mathrm{a})$ may be evinced by the ability of the trustee to exercise broad powers or discretions for his/her own benefit, whether the trustee is compelled to consider the interests of the other beneficiaries' interests and whether the trustee can act in a conflict of interest. ${ }^{154}$ Additionally, the inhibition of trustee accountability per s $140 \mathrm{~A}(2)$ (b) may be evinced by the absence of fiduciary constraints, trustee exclusion of liability or indemnity clauses and whether the beneficiary is able to know the terms of the trust within the meaning of $\mathrm{s} 51$ of the Act. ${ }^{155}$

The alternative, settlor control inquiry under s 140A(4) will also be based on factors identified in the jurisprudence and literature. For example, real settlor control may exist where the settlor has powers to give binding directions on investment, to replace trustees, to distribute assets contrary to the terms of the trust deed or to act as a director of a company whose shares are owned by the trust. ${ }^{156}$

However, s 140A can be considered a substantive reform in three respects. First, it alters the approach of the courts in coming to a determination on whether the trust deed in fact creates a trust. Section 140A(1) incorporates the concept of an illusory trust into the Act. This is important. It preempts courts to resolve trusts disputes using principles of trusts law. The current approach is to dance around the issue of the boundaries of the trust, and resolve disputes principally by reference to external regimes such as relationship property. Second, s 140A(5) provides that where the trust is illusory, the trust is a resulting trust. ${ }^{157} \mathrm{~A}$ resulting trust will require the recipient of the legal title (the "trustee"), to retain the property for the transferor (the "settlor"). ${ }^{158}$ The property is legally and beneficially the transferors', and can be accessed by creditors. This is a substantive change, as a resulting trust has different consequences to merely looking through the trust for the purposes of an external regime. A resulting trust causes the purported trust to be set aside. Contrastingly, external regimes enable access to the trust property for a limited purpose, but the trust otherwise subsists. Third, s 140A(6) confers broad discretion on the courts as to whether to declare the trust illusory. Under s 140A(6), the court

154 Clayton (HC judgment), above n 27, at [81]. The presence of these factors were integral to a finding of an illusory trust in that case.

155 Bennett, above n 5, at 70. See also Palmer and Peart, above n 39, at 118

156 Bennett, above n 5, at 69. See also Kain v Hutton [2008] NZSC 61, [2008] 3 NZLR 589; and Wv W (Practice Note) [2007] NZCA 30, [2007] 2 NZLR 261

157 The resulting trust is referred to in s 5(2)(b)(i) of the Act, but is not defined. It must be taken to have its ordinary, common law meaning.

158 Jessica Palmer "Resulting Trusts" in Andrew Butler and others (ed) Equity and Trusts in New Zealand (2nd ed, Thomson Reuters, Wellington, 2009) 307 at 308. 
may decline to make a declaration if to do so would prejudicially affect the interests of other parties. This is because a declaration will necessitate a resulting trust. Applying the external regime may therefore create a more just result, where a beneficial or other interest needs to be maintained. For these reasons, s 140A is a substantive reform of New Zealand's trust law. It needs to be justified as such.

It has been persuasively argued we ought to be slow to reform the common law on the mere basis "it appears to be untidy and unduly complex". ${ }^{159}$ Further, it is hard to point to any recent trusts case in which injustice appears to have been done simply because the court has found itself constrained by unsatisfactory doctrine. While the reasoning of the appellate Courts in Clayton was messy, the result was a just one, in that Mrs Clayton was able to access her share of the property. Scholars have advocated that the legislature should only intervene in the common law where courts, "shackled by the doctrine of precedent, have lost the required flexibility to reach the appropriate results". ${ }^{160}$ Additionally, many scholars have faith in the ability of common law judges to affect realistic doctrinal reforms where reason or fairness demands. ${ }^{161}$ One has argued that the common law should be trusted to "clean its own house". ${ }^{162}$ Due to a lack of substantive injustice in the law of trusts, one might consider a substantive reform to be unnecessary.

However, s 140A does not seek correct injustice in the law of trusts, nor iron out its complexities. Rather, it recognises fundamental trust concepts and gives them practical effect. As has already been explained, courts are upholding structures that cannot objectively be considered as trusts. Paired with the tendency of the courts to dance around discussion of core trust principles, and exacerbated by pervasive external regimes, there may be a movement from an appreciation of the flexibility of the trust, to a much more dangerous flexibility in our characterisations of what the trust's essential features are. ${ }^{163}$ Section $140 \mathrm{~A}$ gives the courts a practical tool by which they can manage these essential features, and preserve the core of the trust.

\section{B Conferring Discretion}

Section 140A will enable the court to decline to make a declaration of an illusory trust if it considers the interests of other parties will be prejudicially affected. This confers an element of judicial discretion. Some practitioners and scholars will be opposed to this discretion, because of an

159 David McLauchlan "Contract and Commercial Law Reform in New Zealand" (1984) 11 NZULR 36 at 42

160 At 41 .

161 Stephen Waddams "Legislation and Contract Law" (1979) 17 UWO L Rev 185 at 186-190.

162 Edward Belobaba "The Resolution of Common Law Doctrinal Problems Through Legislative and Administrative Intervention" in Barry Reiter and John Swan (eds) Studies in Contract Law (Butterworths, Toronto, 1980) 423 at 423 .

163 Penner "Exemptions", above n 21, at 254. 
ostensible lack of certainty and predictability it gives to the illusory trust inquiry. ${ }^{164}$ As Virgo explains, "[t]he language of judicial discretion appears to allow for the judge to secure what he or she considers to be the just result with reference to the particular facts of the case. "165 Indeed, this author contemplates that many declarations of an illusory trust will hinge on whether the interests of other parties would be prejudicially affected, in the opinion of the court.

Importantly, the New Zealand judiciary and legal commentators appear generally content about the legitimacy of the exercise of judicial discretion. ${ }^{166}$ Virgo, reflecting on HLA Hart's revered posthumous essay on discretion, explains that "judicial discretion is guided by rational principles, so that a decision which is not susceptible to principled justification is not an exercise of discretion, but a mere arbitrary choice". ${ }^{167}$ Certainly, it is contemplated that the courts will build up their own principles for the exercise of discretion. As Burrows notes, our courts have "never been slow to state what considerations judges may and may not take into account when exercising discretion". ${ }^{168}$ As such, precedents inevitably arise. ${ }^{169}$ It is unlikely those precedents will be departed from in later cases where the facts are the same. ${ }^{170}$ Additionally, courts are guided in their exercise of discretion by the purpose, context and scheme of the statute concerned. ${ }^{171}$ This will provide an amount of flexibility (especially considering the equitable origins of trusts law), but will also provide guidance. Further, appellate courts can contribute much to the consistency of decisions if they are prepared to reverse idiosyncratic exercises of discretion by lower courts, and by pointing out how those courts erred. ${ }^{172}$ Finally, in light of the scheme of the Act, s 140A should not be overly prescriptive; conferring an element of discretion through which the courts can develop the doctrine is consonant with the scheme of the Act.

\section{External Regimes are a Secondary Consideration}

There is an argument that s $140 \mathrm{~A}$ is superfluous, due to the ability of external regimes to look through the trust. Trusts enable settlors and beneficiaries to access government benefits as well as to

164 Graham Virgo "Judicial Discretion in Private Law" (2016) 14 Otago L Rev 257.

165 At 259

166 At 257

167 At 260. See generally HLA Hart "Discretion" (2013) 127 Harv L Rev 652.

168 John Burrows "Contract Statutes: The New Zealand Experience" (1983) 4 Statute L Rev 76 at 87. Burrows was writing in the context of New Zealand's discretion-enhancing contract law reforms of the 1970s and 1980s.

169 At 86.

170 At 88 .

171 Broadlands Rentals Ltd v R D Bull Ltd [1974] 2 NZLR 595 (CA) at 600.

172 Burrows, above n 168, at 88 . 
avoid obligations. ${ }^{173}$ The use of trusts in this regard has been met with a variety of legislative responses that look through the trust, so that trust assets can be considered to be the settlor's or beneficiaries' own assets for certain purposes. ${ }^{174}$ External legislative responses can be categorised as either responding to private interests or government interests. ${ }^{175}$ Private interests pertain to the claims of creditors ${ }^{176}$ and relationship property. ${ }^{177}$ Government interests principally relate to income tax ${ }^{178}$ and means-tested social support. ${ }^{179}$

However, look through provisions are of an entirely different nature to s 140A. Look through provisions do not challenge the validity of the trust itself. They recognise that a settlor has used a trust structure to avoid a particular regime, so will treat the trust property as the settlor's for the purposes of that regime. Section 140A simply says what you created cannot be a trust; the trust deed has particular provisions which omit the fundamental tenets of the trust. Section 140A is not intended to affect the applicability of look through provisions. The applicability of external regimes to the trust will be a matter for the court to consider in determining whether making a declaration of an illusory trust would prejudicially affect the interests of other parties.

\section{SECTION 140A IN PRACTICE}

Section 140A strikes the appropriate balance between structures which go beyond the permissible conceptual boundaries of the trust, as in Clayton, and structures which, although flexible and discretionary, remain within those boundaries. This includes the discretionary family trust. To show that discretionary family trusts are not at risk of being found illusory, this article will analyse the VRPT trust deed in Clayton and a typical family trust deed under the proposed s 140A. The relevant provisions of the VRPT trust deed in Clayton have been set out in Part II(B) of this article. The family trust deed is based upon a deed of which the author is aware, and in accordance with the common

173 Law Commission Some Issues with the Law of Trusts in New Zealand: Review of the Law of Trusts Second Paper, above n 58, at 17.

174 At 17.

175 At 17.

176 Sections 344-350 of the Property Law Act 2007 enable the court to set aside certain dispositions of property that "prejudice" creditors. This includes certain transfers of property to a trust.

177 Section 44 of the Property (Relationships) Act 1976 provides that dispositions of property may be set aside if they were made "in order to defeat the claim or rights of any person" under the Act. "Disposition" includes the settlement of assets on a trust.

178 The Income Tax Act 2007 contains a number of provisions that can make the settlor or beneficiary liable to income tax on income from the trust fund. However, there is no express look through provision empowering Inland Revenue to disregard a trust and access its assets.

179 See generally Law Commission Some Issues with the Law of Trusts in New Zealand: Review of the Law of Trusts Second Paper, above n 58, at 31-35. Several statutory provisions allow the government to take account of an interest in a trust for the purposes of assessing a person's assets or income. 
features of a discretionary family trust, per the New Zealand Law Society's guidelines on family trusts. ${ }^{180}$ Its relevant provisions are set out below.

\section{A Clayton Trust}

First, one must consider whether the VRPT deed in substance omits a fiduciary relationship in which the trustee holds or deals with trust property for the benefit of the beneficiaries, under $\mathrm{s}$ 140A(2)(a). As Hansen J established in the High Court, the deed empowered Mr Clayton to use and invest the property in any way he wished. ${ }^{181} \mathrm{Mr}$ Clayton could exercise any of his broad powers or discretions for his own benefit. ${ }^{182}$ The trust is not illusory on this basis alone. If Mr Clayton appointed property to himself as beneficiary, he would be exercising a fiduciary power and would be subject to the traditional mechanisms used to control the exercise of that power. ${ }^{183}$ However, the VRPT deed provided that Mr Clayton could exercise any of his broad powers or discretions for his own benefit, without regard for the other beneficiaries' interests, and notwithstanding any conflict of interest with the VRPT or other beneficiaries. ${ }^{184}$ At this point, the trust deed in substance omits a fiduciary relationship in which the trustee holds or deals with trust property for the benefit of the beneficiaries. Mr Clayton can completely disregard all other interests in relation to the trust. This is directly on point with s 140A(2)(a) and goes toward a finding of an illusory trust.

Powers to appoint and remove trustees and beneficiaries will not ordinarily jeopardise the fiduciary nature of the relationship. Indeed, powers of appointment are fiduciary powers, and are subject to the traditional mechanisms of control of a fiduciary power. The difference here is that $\mathrm{cl} 11$ of the VRPT deed purports to exclude the fiduciary nature of the power. Clause 11 provides that the trustee's powers may be exercised notwithstanding that the interests of all beneficiaries are not considered, the exercise would be contrary to the interests of any beneficiary, or the trustee is in a conflict of interest. In this sense, the powers of appointment under the VRPT trust deed could be seen as jeopardising the fiduciary nature of the relationship between the trustee and beneficiaries.

Second, trustee accountability needs to be considered under s 140A(2)(b). If the fiduciary nature of the relationship is excluded, the trust deed will likely prevent the trustee from being accountable for the way the trustee carries out the duties imposed on the trustee by law. In other words, s $140 \mathrm{~A}(2)$ (b) will usually be satisfied as a consequence, although other provisions of the trust deed may be relevant. The VRPT deed excludes trustee liability for breach of trust except in the case of

180 New Zealand Law Society, above n 136.

181 Clayton (HC judgment), above n 27, at [90].

182 At [81].

183 See Part IV(C)(2).

184 Clayton (HC judgment), above n 27, at [81]. 
dishonesty or wilful breach. ${ }^{185}$ This is a factor going against meaningful accountability. However, some exclusion of liability is consistent with s 40 of the Act. ${ }^{186}$ Another factor is Mr Clayton's ability to appoint and remove discretionary beneficiaries. ${ }^{187} \mathrm{Mr}$ Clayton has this power in his capacity as Principal Family Member of the VRPT, but the power is properly considered under trustee accountability, as an exercise of the power will affect the way in which the trustee is accountable to the beneficiary. A beneficiary is less likely to call the trustee, Mr Clayton, to account if they are removable at the will of the Principal Family Member, who is also Mr Clayton. These factors, in addition to the exclusion of a fiduciary relationship, mean s $132 \mathrm{~A}(2)(\mathrm{b})$ is satisfied. Therefore, in considering s $132 \mathrm{~A}(2)$ (a) and $132 \mathrm{~A}(2)(\mathrm{b})$, it can be said that in substance, the terms of the VRPT deed provide no meaningful accountability on the part of the trustee, to the beneficiaries. A declaration of an illusory trust follows.

Under s 132A(5), the illusory trust is a resulting trust for the settlor, Mr Clayton. The VRPT property is simply Mr Clayton's property, and becomes subject to the equal sharing regime under the PRA. Practically, nothing changes for Mrs Clayton. She has recourse to the assets of the trust to the same extent as if Mr Clayton's powers under the VRPT were treated as "property". The benefit, however, lies in the condemnation of the "trust" structure that was established, thus affirming the boundaries of the trust. If for some reason Mrs Clayton's interests were unfairly prejudiced due to the property being placed on resulting trust, the court could exercise its discretion and refrain from making a declaration of an illusory trust. The court would instead use the external, relationship property regime to give effect to Mrs Clayton's interests.

\section{B Family Trust}

Andrea, the settlor, constitutes the Family Trust (FT) trust deed. Andrea is a co-trustee along with her solicitor, Ben. The discretionary beneficiaries are Andrea and her children, Charlie and Devon. The final beneficiaries are Charlie and Devon. The relevant provisions of the FT trust deed are as follows:

\section{0 - Income distribution}

10.1 The Trustees may pay or apply all or any part of the income of the Trust Fund to or for such one or more of the Discretionary Beneficiaries.

\section{1 - Distribution of capital before vesting day}

185 VRPT Deed, cl 21.1 in Clayton (CA judgment), above n 27, at [25].

186 Notwithstanding the issue of gross negligence. The VRPT deed would be in breach of s 40 as it purports to exclude liability for gross negligence. However, s 40 was not (and is still not) in effect at the time the VRPT deed was constituted, so this cannot be considered in the analysis.

187 VRPT Deed, cl 7.1 in Clayton (CA judgment), above n 27, at [25]. 
11.1 The Trustees may pay, apply or appropriate any part or all of the capital of the Trust Fund to or for such one or more of the Discretionary Beneficiaries.

\section{2 - Powers of appointment}

12.1 The Trustees have the power to appoint and remove Trustees.

12.2 The Trustees have the power to appoint and remove Discretionary Beneficiaries.

\section{3 - Liability of Trustees}

13.1 No Trustee shall be liable for any loss incurred by the Trust Fund or by any beneficiary not attributable to that Trustee's own dishonesty, wilful breach or gross negligence.

\section{4 - Amendment of trust deed}

14.1 The Trustees may vary, revoke or enlarge all or any of the provisions of this deed concerning the management or administration of the Trust.

First, the applicability of s $132 \mathrm{~A}(2)(\mathrm{a})$ is considered. Under the FT deed, Andrea is given broad discretionary powers as co-trustee. With the consent of her co-trustee, Andrea can exercise her powers under cls 10 and 11, to receive all the income and capital of the trust respectively. These powers do not render the trust illusory. If Andrea appointed property to herself as beneficiary, she would be exercising a fiduciary power. In contrast to Mr Clayton, Andrea would still have to consider the interests of the beneficiaries and not act in a conflict of interest situation. This is crucial for the validity of the trust. It was the absence of these obligations in the VRPT deed that tipped the trust over the edge. In Andrea's case, however, any exercise of her power would be subject to the traditional mechanisms of control of trustee discretion.

As noted above, Andrea's power as trustee to appoint and remove trustees and beneficiaries (with Ben's consent) does not jeopardise the fiduciary nature of the trust. Nor does her power to amend the trust deed; it only enables a variation of the deed on matters of management or administration of the trust, not on matters of beneficial or fixed interests under the trust. Therefore, the FT deed does not omit a fiduciary relationship in which the trustee holds or deals with trust property for the benefit of the beneficiaries.

Second, the applicability of s $132 \mathrm{~A}(2)(\mathrm{b})$ is assessed. As the FT deed maintains a fiduciary relationship, it is likely that the trustees will be accountable for the way the trustees carry out their duties imposed on the trustees by law. The FT deed will not reach the threshold contemplated in $\mathrm{s}$ $132 \mathrm{~A}(2)(\mathrm{b})$. The exclusion of liability for breaches of trust that are not dishonest, a wilful breach or grossly negligent appears to go against trustee accountability, but this is only one factor. Importantly, exclusion of liability is permitted under s 40 of the Act. The FT deed is consonant with s 40 . Therefore, the FT deed does not prevent trustee accountability. 
The FT deed provides meaningful accountability on the part of the trustees to the beneficiaries. This conclusion has been arrived at after considering the factors required by s $132 \mathrm{~A}(2)$. It has been shown that the s 132A formulation of the illusory trust doctrine will not catch discretionary family trusts. The author has stressed that striking this balance is integral to $\mathrm{s} 132 \mathrm{~A}$.

\section{CONCLUSION}

The illusory trust doctrine is a necessary addition to the Trusts Act. It enables the court to consider the terms of the trust deed as a whole, and come to a determination as to whether a trust is really a trust at all. Without this ability, the courts will continue to dance around the issue of the conceptual boundaries of the trust. The current approach reflects a movement from an appreciation of the flexibility of the trust, to a much more dangerous flexibility in our characterisation of the essential characteristics of trusts.

The no meaningful accountability view articulated in s 132A is entirely consonant with the scheme of the Act and broader policy considerations. It is consistent with the two tenets of the trust recognised in law, and now identified in $\mathrm{s} 13$ of the Act. These features are a fiduciary relationship in which the trustee holds the property for the benefit of the beneficiaries, and trustee accountability. If these features are absent, there is no meaningful accountability, and the trust is illusory. Crucially, s 132A strikes a balance between egregious uses of the "trust", as in Clayton, and socially acceptable discretionary family trusts. Discretionary family trusts are an integral part of how New Zealanders structure their property, and should not be disturbed. Additionally, as a declaration of an illusory trust may not be made if the interests of other parties are prejudicially affected, the application of the view will not interfere with the applicability of external regimes if a more just result would occur under that regime. Therefore, the illusory trust doctrine as reflected in s $132 \mathrm{~A}$ is a necessary and acceptable addition to the Act. 